\title{
Fluorination of some functionalized cycloalkenes through epoxidation and oxirane opening with Deoxofluor or XtalFluor-E
}

\author{
Attila Márió Remete, ${ }^{1}$ Ferenc Fülöp, ${ }^{1,2}$ Loránd Kiss ${ }^{1 *}$
}

${ }^{1}$ Institute of Pharmaceutical Chemistry, University of Szeged, H-6720 Szeged, Eötvös u. 6, Hungary

${ }^{2}$ MTA-SZTE Stereochemistry Research Group, Hungarian Academy of Sciences, H-6720 Szeged, Eötvös u. 6, Hungary

Email: kiss.lorand00@gmail.com

\section{Graphical abstract:}

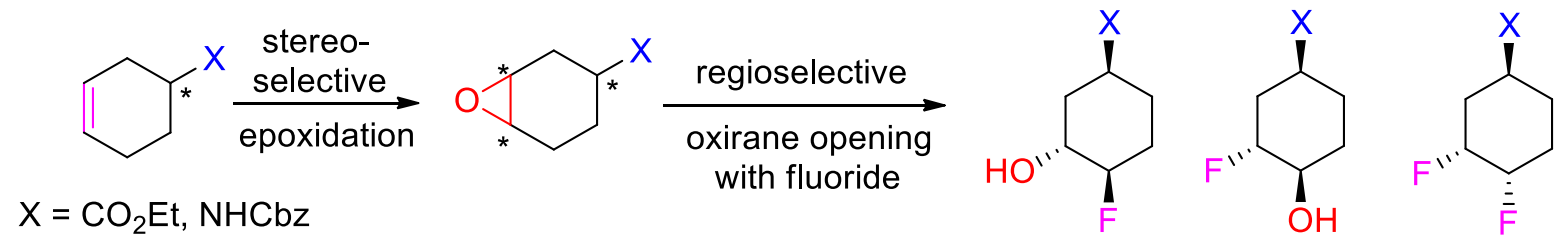

\begin{abstract}
:
A convenient, simple synthetic method is described for the synthesis of some fluorinecontaining, highly functionalized cycloalkane derivatives. The synthetic protocol involves the stereoselective epoxidation of selected substituted cyclohexenes as model compounds, followed by regioselective opening of epoxides under various conditions with fluorinating reagents Deoxofluor and XtalFluor-E.
\end{abstract}

Keywords: cycloalkanes, oxirane, fluorination, selectivity

\section{Introduction}

The epoxidation of a carbon-carbon double bond and the ring opening of resulting oxiranes with a wide range of nucleophiles is a common method to introduce various functional groups onto the skeleton of a certain organic scaffold [1-5].

Because of the high importance of fluorinated biomolecules in drug design, the introduction of one or more fluorine atoms into an organic molecule has attracted high interest 
over the past ten years [6-10]. In view of the significance of a fluorine atom in an organic molecule, epoxide opening with fluoride, without doubt, is a highly useful approach for the introduction of a fluorine atom into a certain molecule [11-13]. Numerous synthetic approaches including asymmetric methodologies have been developed for epoxide opening with fluoride. To name a few, fluorine-containing reagents such as pyridine $\mathrm{HF}$ [14-15], Et $3 \mathrm{~N} \cdot 3 \mathrm{HF}$ [16], $\mathrm{BF}_{3} \cdot \mathrm{OEt}_{2}$ [17], $\mathrm{HBF} 4$ [18], $\mathrm{KHF} 2$ [19], TBAF/KHF $2, \mathrm{TBAF} \cdot 3 \mathrm{H}_{2} \mathrm{O} / \mathrm{KF}$ [20], $\mathrm{KHF}_{2} / 18$-crown6/chiral Jacobsen chromium complex [21], $\mathrm{AgHF}_{2}$ with $\mathrm{Ru}$ catalyst [22], and benzoyl fluoride with a base and HFIP [23] have been reported. In spite of such a plethora of reagents, the stereoand regioselective transformation of varied functionalized alicyclic frameworks is still a challenge. Bicyclic oxirane-fused ring systems, in particular, are still considered to be complicated substrates for ring opening with fluoride. Accordingly, there is certainly a demand for the development of novel methodologies in view of this type of fluorination.

\section{Results and Discussion}

The aim of the current paper is to describe a fluorination protocol based on the oxidative transformation of substituted cyclohexenes through epoxidation, followed by nucleophilic opening of the three-membered $O$-heterocyclic ring system with fluoride by using Deoxofluor or XtalFluor-E reagents. This is a continuation of our effort to explore the chemical behavior of various epoxy-2-aminocyclohexane- or cyclopentanecarboxylates in selective fluorinations described in a recent paper [24]. In addition to study the anchimeric effect of the functional groups, the synergic influence of simultaneously present carboxylate and $\mathrm{N}$-protected amino moieties on the outcome of fluorination was also investigated. Accordingly, in view of these earlier results, here we describe the opening of some oxiranes, which contain only a single functional group on the cyclohexene skeleton: either a carboxylate or a protected amino group.

Our experimental investigation was started with commercially available racemic ethyl cyclohexane-3-carboxylate $( \pm)$-1. First, it was submitted to epoxidation according to a literature procedure [25] furnishing, due to stereochemical factors, epoxycyclohexane esters $( \pm)$-2 and $( \pm)-4$ in yields of $55 \%$ and $29 \%$, respectively. Opening of the epoxide ring in $( \pm)-2$ was attempted under various conditions in view of the fluorinating reagent (Deoxofluor, XtalFluorE), solvent $\left(\mathrm{CH}_{2} \mathrm{Cl}_{2}\right.$, THF or 1,4-dioxane) and temperature. Unfortunately, Deoxofluor did not give any identifiable product. After some attempts, however, we found that the opening of the oxirane ring proceeded with 2 equiv of XtalFluor-E, in the presence of $\mathrm{Et}_{3} \mathrm{~N}$ HF in refluxing dioxane, leading regioselectively through the fluoride attack on C-6 to a fluorine-containing product. The structure of product fluorohydrine $( \pm)-3$ was assigned on the basis of 2D NMR 
data (Scheme 1). Noteworthy, neither of the use of a larger amount of XtalFluor-E reagent, nor Deoxofluor provided the expected hydroxy-fluorine exchange product, only either the unreacted starting ester or decomposed materials were detected.

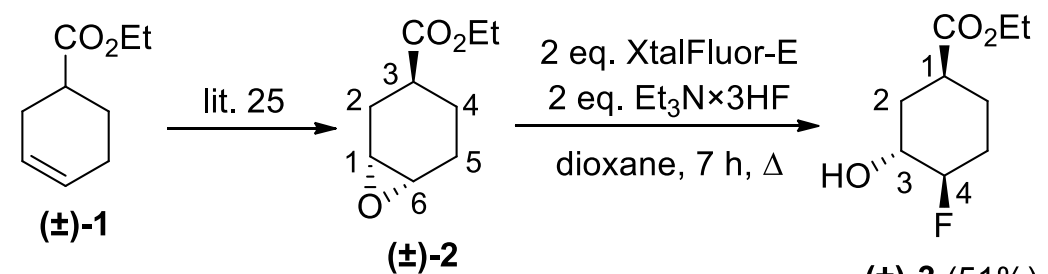

\section{Scheme 1.}

The favoured diaxial conformations during the oxirane opening may explain the regioselectivity of the above reaction. The attack of the fluoride ion to the oxirane ring at position C-6 leads to the favoured chair diaxial conformation with the hydroxy and fluorine located in axial positions, affording the 4-fluorinated derivative. The fluoride ion attack to the oxirane ring at position C1 would generate an unfavoured twisted chair diaxial conformation with the fluorine and hydroxy groups in diaxial orientations; therefore the corresponding 3-fluorinated derivative was not formed (Scheme 2; note: the difference in the numbering of the epoxide system and the fluoro-substituted product!).

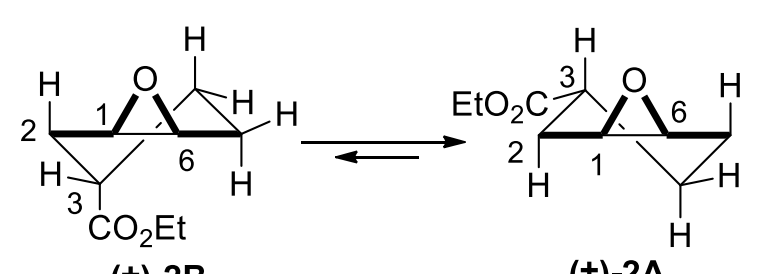

$( \pm)-2 B$

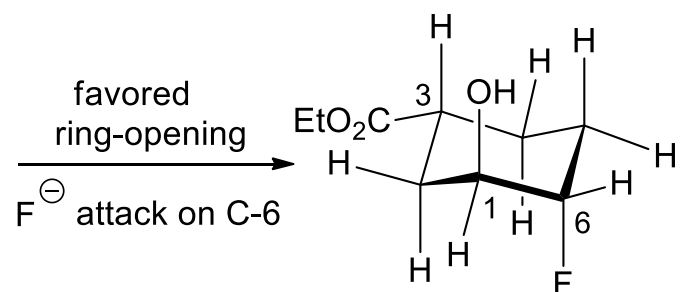

$( \pm)-3$

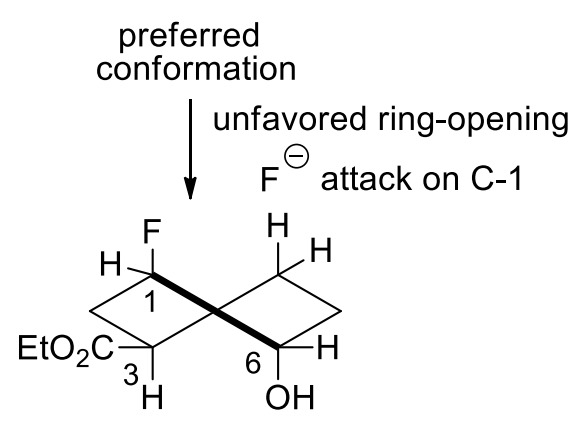

Scheme 2.

Next, epoxide ( \pm )-4 was subjected to fluorination under various experimental conditions. 2 equiv of XtalFluor-E induced oxirane ring opening in the presence of $\mathrm{Et}_{3} \mathrm{~N} \cdot \mathrm{HF}$ in refluxing 
dioxane and furnished regioselectively a fluorinated product, which was identified according to 2D NMR data as compound ( \pm )-5, with the fluorine attached to C-3 on the cyclohexane skeleton.<smiles>CCOC(=O)C1CC=CCC1</smiles>

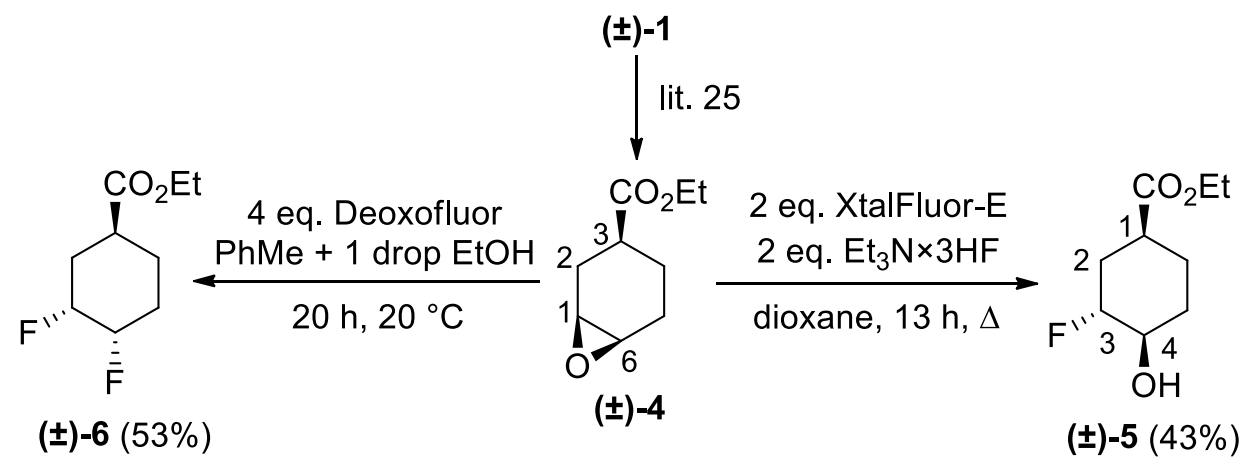

\section{Scheme 3.}

Again, the regiosolectivity of this epoxide opening may be explained by a favourable diaxial chair conformation as depicted in Scheme 4.

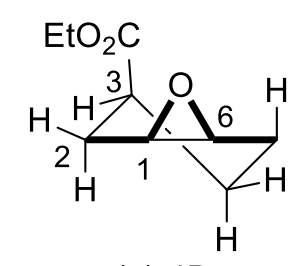

$( \pm)-4 \mathrm{~B}$
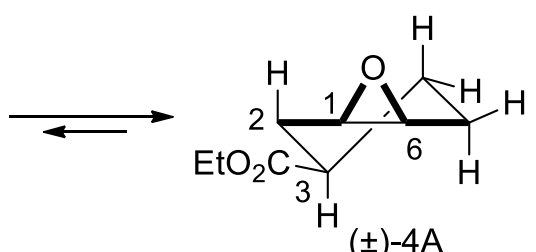

$( \pm)-4 \mathrm{~A}$

preferred conformation

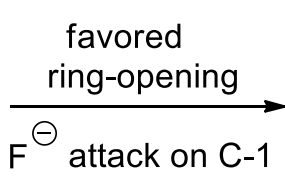
$\mathrm{F}^{\ominus}$ attack on $\mathrm{C}-1$ unfavored ring-opening

$\downarrow \mathrm{F}^{\ominus}$ attack on $\mathrm{C}-6$

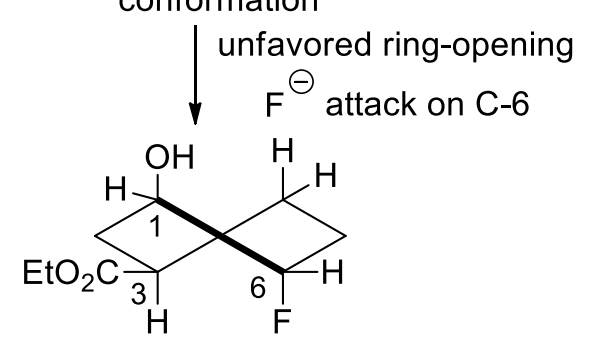

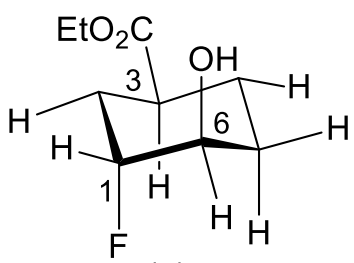

$( \pm)$

\section{Scheme 4.}

Further attempts to exchange the newly created hydroxy group in ( \pm )-5 for fluorine, either by XtalFluor-E or Deoxofluor remained uneffective. Interestingly, contrary to the behaviour of epoxide $( \pm)$-2, stereoisomer $( \pm)-4$ with 4 equiv of Deoxofluor in the presence of 1 drop of EtOH in toluene resulted in a fluorinated product, identified as $( \pm)-5$. It was formed in regioselective 
oxirane opening and hydroxy-fluorine substitution through configurational inversion (Scheme $3)$.

In continuation, investigations on amino-substituted cyclohexene were performed. CbzProtected cyclohexene ( \pm )-8, derived from commercially available cyclohex-3-enecarboxylic acid ( \pm )-7 [26], was submitted to epoxidation with MCPBA yielding only a single stereoisomer identified as ( \pm -9 $\mathbf{9}$ in a cis-diastereoslective manner. In this product, the carbamate group and oxirane ring have the same steric arrangement relative to the six-membered ring. The stereoslectivity of this reaction may be attributed to the hydrogen-bonding directing effect in the transition state of the oxidation $[27,28]$. Surprisingly, fluorination of $( \pm)-9$ with XtalFluorE did not afford any identifiable product. In contrast, the reaction with Deoxofluor induced fluorination through regioselective epoxide opening, followed by hydroxy-fluorine interconversion leading to difluorinated derivative $( \pm)-\mathbf{1 0}$ as the sole product (Scheme 5). Compare this to a similar process to form $( \pm)-6$ shown in Scheme 3.

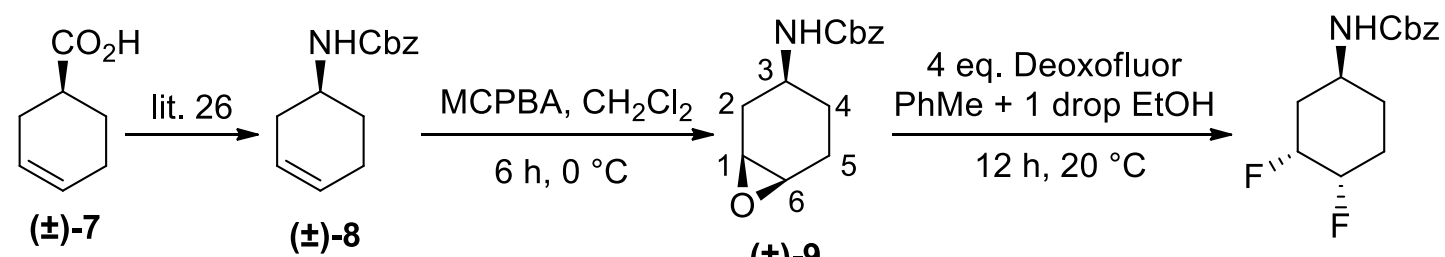

$( \pm)-9$

(士)-10 (48\%)

\section{Scheme 5.}

\section{Conclusions}

Cyclohexene derivatives as model compounds have been studied in an oxidation and fluorination sequence to access highly functionalized fluorine-containing alicyclic scaffolds. The synthetic procedure was based on the epoxidation of the ring olefinic bond followed by ring opening of the resulting functionalized cyclohexane-fused oxiranes with both XtalFluor-E and Deoxofluor as fluorinating reagents.

\section{Experimental}

\section{General information:}

Chemicals were purchased from Sigma-Aldrich. Solvents were used as received from the suppliers. Melting points were determined with a Kofler apparatus. Elemental analyses were performed with a Perkin-Elmer CHNS-2400 Ser II elemental analyser. Silica gel 60 F254 was purchased from Merck. NMR spectra were acquired at room temperature on a Bruker Avance 
400 spectrometer with $11.75 \mathrm{~T}$ magnetic field strength $\left({ }^{1} \mathrm{H}\right.$ frequency $400.13 \mathrm{MHz} ;{ }^{19} \mathrm{~F}$ frequency $376.50 \mathrm{MHz},{ }^{13} \mathrm{C}$ frequency $100.76 \mathrm{MHz}$ ) in $\mathrm{CDCl}_{3}$ or $\mathrm{D}_{6}$-DMSO solution, using the deuterium signal of the solvent to lock the field. The ${ }^{1} \mathrm{H}$ and ${ }^{13} \mathrm{C}$ chemical shifts are given relative to TMS and ${ }^{19} \mathrm{~F}$ to $\mathrm{CFCl}_{3}(0.00 \mathrm{ppm})$.

Ethyl $\left(1 S^{*}, 3 R^{*}, 6 R^{*}\right)-7-0 x a b i c y c l o[4.1 .0]$ heptane-3-carboxylate and ethyl $\left(1 R^{*}, 3 R^{*}, 6 S^{*}\right)$ 7-oxabicyclo[4.1.0]heptane-3-carboxylate<smiles>CCOC(=O)C1CCC2(O)CCCC1C2</smiles><smiles>CCOC(=O)C1CCC2OC2C1</smiles>

To a solution of ethyl cyclohex-3-enecarboxylate $(1.87 \mathrm{~g}, 12.1 \mathrm{mmol})$ in $\mathrm{CH}_{2} \mathrm{Cl}_{2}$ (75 mL), 3chloroperbenzoic acid (1.2 equiv) was added. After stirring at room temperature for 2 hours, the reaction mixture was diluted with $\mathrm{CH}_{2} \mathrm{Cl}_{2}(70 \mathrm{~mL})$, washed with a solution of $\mathrm{Na}_{2} \mathrm{SO}_{3}(1.3$ $\mathrm{g}$ in $30 \mathrm{ml}$ saturated aqueous $\mathrm{NaHCO}_{3}$ solution), then washed with $2 \times 30 \mathrm{ml}$ saturated $\mathrm{NaHCO}_{3}$ solution. The organic layer was dried $\left(\mathrm{Na}_{2} \mathrm{SO}_{4}\right)$ and concentrated. The product mixture was separated by column chromatography on silica gel ( $n$-hexane/EtOAc). Yields: $55 \%$ ethyl $\left(1 S^{*}, 3 R^{*}, 6 R^{*}\right)$-7-oxabicyclo[4.1.0] heptane-3-carboxylate and $29 \%$ ethyl $\left(1 R^{*}, 3 R^{*}, 6 S^{*}\right)-7$ oxabicyclo[4.1.0]heptane-3-carboxylate (lit. 25).

\section{Benzyl $\left(1 S^{*}, 3 S^{*}, 6 R^{*}\right)$-7-oxabicyclo[4.1.0]heptan-3-ylcarbamate}

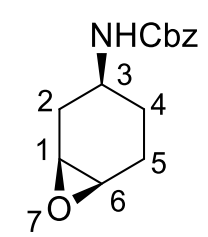

Benzyl cyclohex-3-en-1-ylcarbamate (0.50 g, $2.16 \mathrm{mmol})$ was dissolved in $\mathrm{CH}_{2} \mathrm{Cl}_{2}(25 \mathrm{~mL})$, cooled to $0{ }^{\circ} \mathrm{C}$, then 3 -chloroperbenzoic acid (1.2 equiv) was added. After stirring for 4 hours, during which the reaction mixture was allowed to warm up to room temperature, the reaction mixture was diluted with $\mathrm{CH}_{2} \mathrm{Cl}_{2}(25 \mathrm{~mL})$, washed with a solution of $\mathrm{Na}_{2} \mathrm{SO}_{3}(0.5 \mathrm{~g}$ in $25 \mathrm{ml}$ saturated aqueous $\mathrm{NaHCO}_{3}$ solution), then washed with $2 \times 25 \mathrm{ml}$ saturated $\mathrm{NaHCO}_{3}$ solution. The organic layer was dried $\left(\mathrm{Na}_{2} \mathrm{SO}_{4}\right)$ and concentrated. The crude product was purified by column chromatography on silica gel ( $n$-hexane/EtOAc).

White solid; Yield 75\%; $\mathrm{R}_{\mathrm{f}}=0.50$ ( $n$-hexane/EtOAc 3:2); Mp 56-65 ${ }^{\circ} \mathrm{C} .{ }^{1} \mathrm{H}-\mathrm{NMR}(400 \mathrm{MHz}$, $\mathrm{D}_{6}$-DMSO, TMS) $\delta=1.18-1.31$ (m, 1H, H-4), 1.34-1.43 (m, 1H, H-4), 1.52-1.62 (m, 1H, H-2), 
1.75-1.87 (m, 1H, H-5), 1.98-2.07 (m, 1H, H-5), 2.12-2.22 (m, 1H, H-2), 3.01-3.09 (m, 2H, H1 and H-6), 3.21-3.28 (m, 1H, H-3), 4.99 (s, 2H, $\left.\mathrm{OCH}_{2}\right), 7.08$ (d, $\left.J=7.40 \mathrm{~Hz}, 1 \mathrm{H}, \mathrm{NH}\right), 7.27-$ 7.40 (m, 5H, CH-Ar). ${ }^{13} \mathrm{C}$ NMR (100 MHz, D6-DMSO, TMS) $\delta=24.6,25.5,31.0,46.2,51.2$, 51.8, 66.0, 128.6, 129.2, 138.1, 156.1. MS (ESI, pos) m/z $248(\mathrm{M}+1)$. Anal. Calcd. for $\mathrm{C}_{14} \mathrm{H}_{17} \mathrm{NO}_{3}$ : C, 68.00; H, 6.93; N, 5.66. Found: C, 67.69; H, 6.66; N, 5.31.

\section{General procedures for oxirane ring opening with fluoride:}

\section{Method A}

To a solution of starting epoxide $(0.50-0.75 \mathrm{mmol})$ in anhydrous toluene $(10 \mathrm{~mL})$ under an $\mathrm{Ar}$ atmosphere, one drop of $\mathrm{EtOH}$ and 50\% Deoxofluor in toluene (4 equiv) were added and the solution was stirred at $20{ }^{\circ} \mathrm{C}$ for the time given in the text. The solution was then diluted with $\mathrm{CH}_{2} \mathrm{Cl}_{2}(30 \mathrm{~mL})$ and the organic layer was washed with saturated aqueous $\mathrm{NaHCO}_{3}$ solution (2 $\times 20 \mathrm{~mL})$. The organic layer was dried $\left(\mathrm{Na}_{2} \mathrm{SO}_{4}\right)$ and concentrated. The crude product was purified by column chromatography on silica gel ( $n$-hexane/EtOAc).

\section{Method B}

To a solution of starting epoxide $(0.50-0.75 \mathrm{mmol})$ in 1,4-dioxane $(10 \mathrm{~mL})$ under an $\mathrm{Ar}$ atmosphere $\mathrm{Et}_{3} \mathrm{~N} \cdot 3 \mathrm{HF}$ ( 2 equiv) was added, followed by the addition of XtalFluor-E (1 equiv). The reaction mixture was refluxed for the time given in the text. The solution after cooling was diluted with $\mathrm{CH}_{2} \mathrm{Cl}_{2}(30 \mathrm{~mL})$ and the organic layer was washed with saturated aqueous $\mathrm{NaHCO}_{3}$ solution $(2 \times 20 \mathrm{~mL})$. The organic layer was dried $\left(\mathrm{Na}_{2} \mathrm{SO}_{4}\right)$ and concentrated. The crude product was purified by column chromatography on silica gel ( $n$-hexane/EtOAc or $n$-hexane/acetone).

Ethyl $\left(1 S^{*}, 3 R^{*}, 4 R^{*}\right)$-4-fluoro-3-hydroxycyclohexanecarboxylate<smiles>CCOC(=O)C1CCC(F)[C@H](O)C1</smiles>

Colorless oil; Yield 51\%; $\mathrm{R}_{\mathrm{f}}=0.47$ (n-hexane/EtOAc 2:1). ${ }^{1} \mathrm{H}-\mathrm{NMR}$ (400 MHz, $\mathrm{CDCl}_{3}$, TMS) $\delta=1.27\left(\mathrm{t}, J=7.12 \mathrm{~Hz}, 3 \mathrm{H}, \mathrm{CH}_{3}\right), 1.56-1.83(\mathrm{~m}, 3 \mathrm{H}, \mathrm{H}-2, \mathrm{H}-5$ and H-6), 1.89-2.09 (m, 2H, H5 and H-6), 2.19-2.31 (m, 1H, H-2), 2.67-2.79 (m, 1H, H-1), 3.90-4.02 (m, 1H, H-3), 4.16 (q, $J$ $\left.=7.12 \mathrm{~Hz}, 2 \mathrm{H}, \mathrm{OCH}_{2}\right), 4.28-4.49(\mathrm{~m}, 1 \mathrm{H}, \mathrm{H}-4) .{ }^{19} \mathrm{~F} \mathrm{NMR}\left(376 \mathrm{MHz}, \mathrm{CDCl}_{3}\right) \delta=-184.71 .{ }^{13} \mathrm{C}$ NMR (100 MHz, $\mathrm{CDCl}_{3}$, TMS) $\delta=14.6,24.3$ and $24.4\left({ }^{3} J=7.21 \mathrm{~Hz}\right), 26.7$ and $26.9\left({ }^{2} J=\right.$ 
$19.17 \mathrm{~Hz}), 32.2$ and $32.3\left({ }^{3} J=3.64 \mathrm{~Hz}\right), 38.1,61.0,69.1$ and $69.3\left({ }^{2} J=22.58 \mathrm{~Hz}\right), 92.9$ and 94.6 $\left({ }^{1} J=172.97 \mathrm{~Hz}\right), 174.9$. Anal. Calcd. for $\mathrm{C}_{9} \mathrm{H}_{15} \mathrm{FO}_{3}$ : C, 56.83; H, 7.95. Found: C, 56.53; H, 7.69.

Ethyl $\left(1 S^{*}, 3 R^{*}, 4 R^{*}\right)-3$-fluoro-4-hydroxycyclohexanecarboxylate<smiles>CCOC(=O)C1CCC(O)C(F)C1</smiles>

Colorless oil; Yield 43\%; $\mathrm{R}_{\mathrm{f}}=0.41$ ( $n$-hexane/acetone 4:1). ${ }^{1} \mathrm{H}-\mathrm{NMR}$ (400 MHz, $\mathrm{CDCl}_{3}, \mathrm{TMS}$ ) $\delta=1.27\left(\mathrm{t}, J=7.12 \mathrm{~Hz}, 3 \mathrm{H}, \mathrm{CH}_{3}\right), 1.51-1.69$ (m, 2H, H-5 and H-6), 1.74-1.86 (m, 1H, H-2), 1.86-2.07 (m, 2H, H-5 and H-6), 2.23-2.41 (m, 1H, H-2), 2.70-2.79 (m, 1H, H-1), 3.73-3.84 (m, $1 \mathrm{H}, \mathrm{H}-4), 4.15$ (q, $\left.J=7.12 \mathrm{~Hz}, 2 \mathrm{H}, \mathrm{OCH}_{2}\right), 4.49-4.70$ (m, 1H, H-3). ${ }^{19} \mathrm{~F}$ NMR (376 MHz, $\left.\mathrm{CDCl}_{3}\right) \delta=-185.90 .{ }^{13} \mathrm{C} \mathrm{NMR}\left(100 \mathrm{MHz}, \mathrm{CDCl}_{3}\right.$, TMS $) \delta=14.6,24.3,28.4$ and $28.5\left({ }^{3} \mathrm{~J}=\right.$ $3.76 \mathrm{~Hz}), 30.2$ and $30.4\left({ }^{2} J=19.83 \mathrm{~Hz}\right), 38.8$ and $38.9\left({ }^{3} J=7.28 \mathrm{~Hz}\right), 61.1,70.5$ and $70.7\left({ }^{2} J\right.$ $=22.29 \mathrm{~Hz}), 91.8$ and $93.5\left({ }^{1} \mathrm{~J}=171.89 \mathrm{~Hz}\right)$, 174.7. Anal. Calcd. for $\mathrm{C}_{9} \mathrm{H}_{15} \mathrm{FO}_{3}: \mathrm{C}, 56.83 ; \mathrm{H}$, 7.95. Found: C, 56.51; H, 8.38.

Ethyl $\left(1 S^{*}, 3 R^{*}, 4 S^{*}\right)-3,4-$ difluorocyclohexanecarboxylate<smiles>CCOC(=O)C1CCC(F)C(F)C1</smiles>

Colorless oil; Yield 53\%; $\mathrm{R}_{\mathrm{f}}=0.47$ (n-hexane/EtOAc 9:1). ${ }^{1} \mathrm{H}-\mathrm{NMR}\left(400 \mathrm{MHz}, \mathrm{CDCl}_{3}\right.$, TMS) $\delta=1.26\left(\mathrm{t}, J=7.14 \mathrm{~Hz}, 3 \mathrm{H}, \mathrm{CH}_{3}\right), 1.49-1.64(\mathrm{~m}, 1 \mathrm{H}, \mathrm{H}-6), 1.70-1.88(\mathrm{~m}, 1 \mathrm{H}, \mathrm{H}-2), 1.88-2.14$ (m, 3H, $2 \times \mathrm{H}-5$ and H-6), 2.26-2.39 (m, 1H, H-2), 2.66-2.76 (m, 1H, H-1), 4.14 (q, J = 7.12 $\mathrm{Hz}, 2 \mathrm{H}, \mathrm{OCH}_{2}$ ), 4.41-4.67 (m, 1H, H-4), 4.84-5.06 (m, 1H, H-3). ${ }^{19} \mathrm{~F}$ NMR (376 MHz, $\mathrm{CDCl}_{3}$ ) $\delta=-188.58,-200.35 .{ }^{13} \mathrm{C}$ NMR $\left(100 \mathrm{MHz}, \mathrm{CDCl}_{3}\right.$, TMS $\delta=14.6,25.4$ and $25.5\left({ }^{3} J=9.91\right.$ $\mathrm{Hz}), 25.7$ and 25.7 and 25.9 and $25.9\left({ }^{2} J=19.96 \mathrm{~Hz},{ }^{3} J=3.33 \mathrm{~Hz}\right), 31.2$ and 31.2 and 31.4 and $31.4\left({ }^{2} J=20.34 \mathrm{~Hz},{ }^{3} J=5.59 \mathrm{~Hz}\right), 37.1$ and $37.2\left({ }^{3} J=2.93 \mathrm{~Hz}\right), 61.1,87.4$ and 87.6 and 89.2 and $89.3\left({ }^{1} J=177.81 \mathrm{~Hz},{ }^{2} J=17.43 \mathrm{~Hz} 89.3\right.$ and 89.5 and 91.1 and $91.3\left({ }^{1} J=181.41 \mathrm{~Hz},{ }^{2} J=\right.$ 18.18 Hz), 174.8. Anal. Calcd. for $\mathrm{C}_{9} \mathrm{H}_{14} \mathrm{~F}_{2} \mathrm{O}_{2}$ : C, 56.24; H, 7.34. Found: C, 55.88; H, 6.99.

\section{Benzyl $\left(1 S^{*}, 3 R^{*}, 4 S^{*}\right)-3,4-$ difluorocyclohexyl)carbamate}


<smiles>O=C(NC1CCC(F)C(F)C1)OCc1ccccc1</smiles>

White solid; Yield 48\%; $\mathrm{R}_{\mathrm{f}}=0.53$ ( $n$-hexane/EtOAc 2:1); Mp 102-106 ${ }^{\circ} \mathrm{C} .{ }^{1} \mathrm{H}-\mathrm{NMR}(400 \mathrm{MHz}$, D6-DMSO, TMS) $\delta=1.27-1.43$ (m, 1H, H-6), 1.50-1.71 (m, 1H, H-2), 1.72-1.95 (m, 3H, H-6 and $2 \times \mathrm{H}-5), 2.01-2.17$ (m, 1H, H-2), 3.56-3.72 (m, 1H, H-1), 4.57-4.84 (m, 1H, H-4), 4.85$5.12\left(\mathrm{~m}, 3 \mathrm{H}, \mathrm{H}-3\right.$ and $\left.\mathrm{OCH}_{2}\right), 7.21-7.44(\mathrm{~m}, 6 \mathrm{H}, \mathrm{CH}-\mathrm{Ar}$ and $\mathrm{NH}) .{ }^{19} \mathrm{~F}$ NMR $\left(376 \mathrm{MHz}, \mathrm{D}_{6}-\right.$ DMSO) $\delta=-185.60,-196.57 .{ }^{13} \mathrm{C}$ NMR (100 MHz, D 6 -DMSO, TMS $) \delta=25.3$ and $25.5\left({ }^{2} J=\right.$ $20.04 \mathrm{~Hz}), 28.6,34.6$ and $34.8\left({ }^{2} J=19.21 \mathrm{~Hz}\right), 45.2,66.2,88.7$ and 88.9 and 90.4 and $90.6\left({ }^{1} J\right.$ $\left.=174.10 \mathrm{~Hz},{ }^{2} J=17.29 \mathrm{~Hz}\right), 89.5$ and 89.7 and 91.3 and $91.4\left({ }^{1} J=178.17 \mathrm{~Hz},{ }^{2} J=17.80 \mathrm{~Hz}\right)$, 128.7, 129.2, 138.0, 156.3. MS (ESI, pos) m/z $270(\mathrm{M}+1)$. Anal. Calcd. for $\mathrm{C}_{14} \mathrm{H}_{17} \mathrm{~F}_{2} \mathrm{NO}_{2}$ : $\mathrm{C}$, 62.44; H, 6.36; N, 5.20. Found: C, 62.10; H, 6.09; N, 4.86.

\section{Acknowledgments}

We are grateful to the Hungarian Research Foundation (NKFIH Nos. K 115731 and K 119282) for financial support. The financial support of the GINOP-2.3.2-15-2016-00014 project is also acknowledged. This research was supported by the EU-funded Hungarian grant EFOP-3.6.116-2016-00008.

\section{References and Notes}

1. Wang, P. A. Beilstein J. Org. Chem. 2013, 9, 1677-1695.

2. Zhu, Y.; Wang, Q.; Cornwall, R. G.; Shi, Y. Chem. Rev. 2014, 114, 8199-8256.

3. Chawla, R.; Singh, A. K.; Yadav, L. D. S. RSC Adv. 2013, 3, 11385-11403.

4. Meninno, S.; Lattanzi, A. Chem. Eur. J. 2016, 22, 3632- 3642.

5. Kiss, L.; Remete, A. M.; Nonn, M.; Fustero, S.; Sillanpaa, R.; Fülöp, F. Tetrahedron 2016, 72, 781-787 (and references cited therein).

6. Zhou, Y.; Wang, Y.; Gu, Z.; Wang, S.; Zhu, W.; Acena, J. L.; Soloshonok, V. A.; Izawa, K.; Liu, H. Chem. Rev. 2016, 116, 442-518.

7. Wang, J.; Sánchez-Roselló, M.; Aceña, J. L.; del Pozo, C.; Sorochinsky, A. E.; Fustero, S.; Soloshonok, V. A.; Liu, H. Chem. Rev. 2014, 114, 2432-2506.

8. O’Hagan D. J. Fluorine Chem. 2010, 131, 1071-1081.

9. Kiss, L.; Forró, E.; Fustero, S.; Fülöp, F. Eur. J. Org. Chem. 2011, 4993-5001. 
10. Nonn, M.; Kiss, L.; Haukka, M.; Fustero, S.; Fülöp, F. A Org. Lett. 2015, 17, 1074-1077 (and references therein).

11. Champagne, P. A.; Desroches, J.; Hamel, J. D.; Vandamme, M.; Paquin, J. F. Chem. Rev. 2015, 115, 9073-9174.

12. Wu, J. Tetrahedron Lett. 2014, 55, 4289-4294.

13. Liang, T.; Neumann, C. N.; Ritter, T. Angew. Chem. Int. Ed. 2013, 52, 8214-8264.

14. Husstedt, W. S.; Wiehle, S.; Stillig, C.; Bergander, C.; Grimme, S.; Haufe, G. Eur. J. Org. Chem. 2011, 355-363.

15. O’Hagan, D. J. Org. Chem. 2012, 77, 3689-3699.

16. Bykova, T.; Al-Maharik, N.; Slawin, A. M. Z.; O’Hagan, D. Org. Biomol. Chem. 2016, 14, $1117-1123$.

17. Fraile, J. M.; Mayoral, J. A.; Salvatella, L. J. Org. Chem. 2014, 79, 5993-5999.

18. Cresswell, A. J.; Davies, S. G.; Lee, J. A.; Morris, M. J.; Roberts, P. M.; Thomson, J. E. J. Org. Chem. 2012, 77, 7262-7281.

19. Kondapi, V. P. K.; Soueidan, O. M.; Hosseini, S. N.; Jabari, N.; West, F. G. Eur. J. Org. Chem. 2016, 1367-1379.

20. Yan, N.; Fang, Z.; Liu, Q. Q.; Guo, X. H.; Hu, X. G. Org. Biomol. Chem. 2016, 14, 34693475 .

21. Haufe, G.; Bruns, S.; Runge, M. J. Fluorine Chem. 2001, 112, 55-61.

22. Althaus, M.; Togni, A.; Mezzetti, A. J. Fluorine Chem. 2009, 130, 702-707.

23. Kalow, J. A.; Doyle, A. G. J. Am. Chem. Soc. 2011, 133, 16001-16012.

24. Remete, A. M.; Nonn, M.; Fustero, S.; Fülöp, F.; Kiss, L. Molecules 2016, 21, 1943.

25. Goss, R. J. M.; Lanceron, S.; Roy, A. D.; Sprague, S.; Nur-e-Alam, M.; Hughes, D. L.;

Wilkinson, B.; Moss, S. J. ChemBioChem 2010, 11, 598-702.

26. Ábrahámi, R. A.; Kiss, L.; Fustero, S.; Fülöp, F. Synthesis 2017, 49, 1206-1213.

27. Kiss, L.; Remete, A. M.; Nonn, M.; Fustero, S.; Sillanpaa, R.; Fülöp, F. Tetrahedron 2016, 72, 781-787.

28. Kiss, L.; Forró, E.; Sillanpää, R.; Fülöp, F. J. Org. Chem. 2007, 72, 8786-8790.

\section{Supporting Information}

\section{${ }^{1} \mathrm{H}-\mathrm{NMR}$ and ${ }^{13} \mathrm{C}$-NMR spectra}



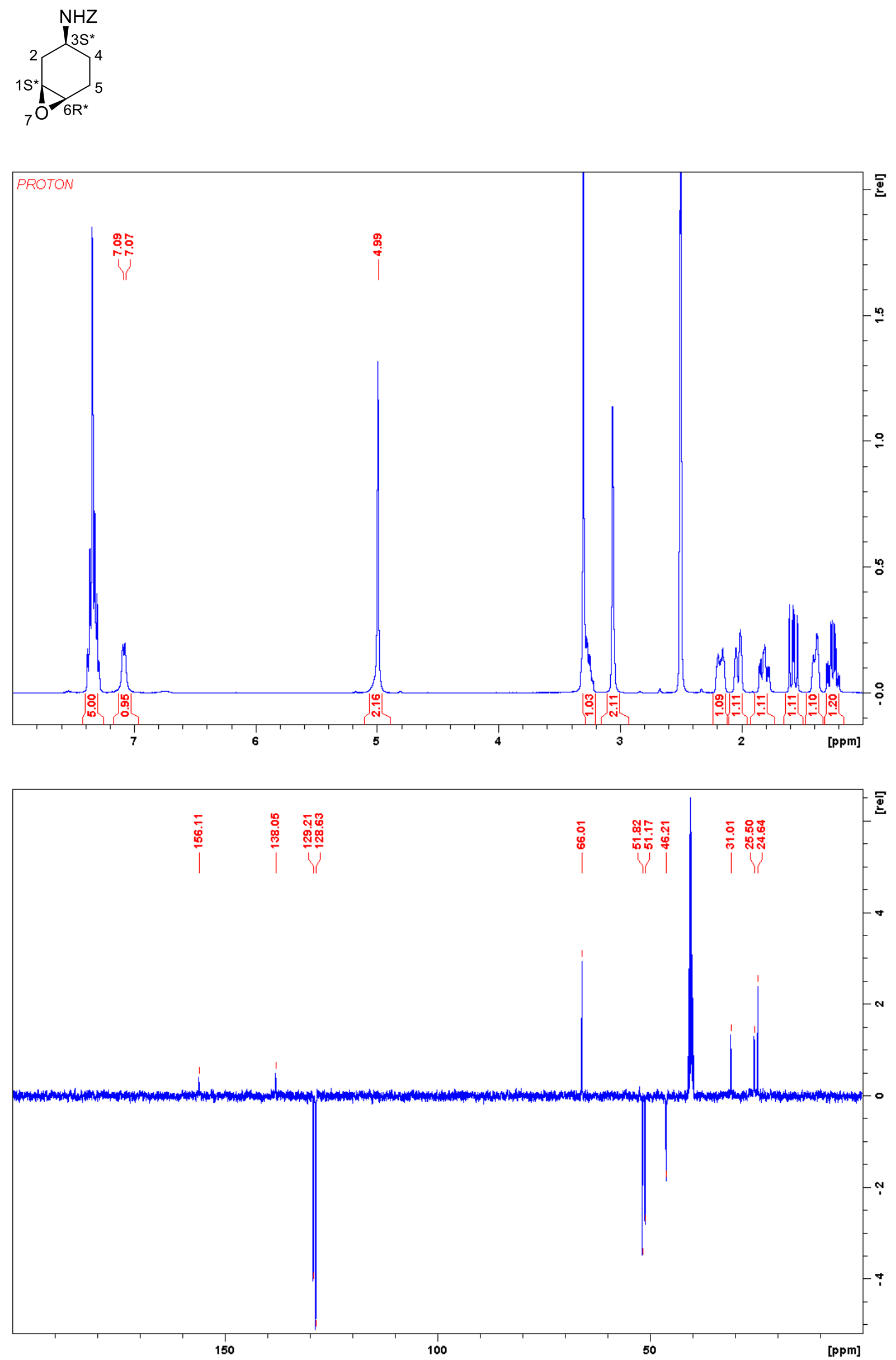

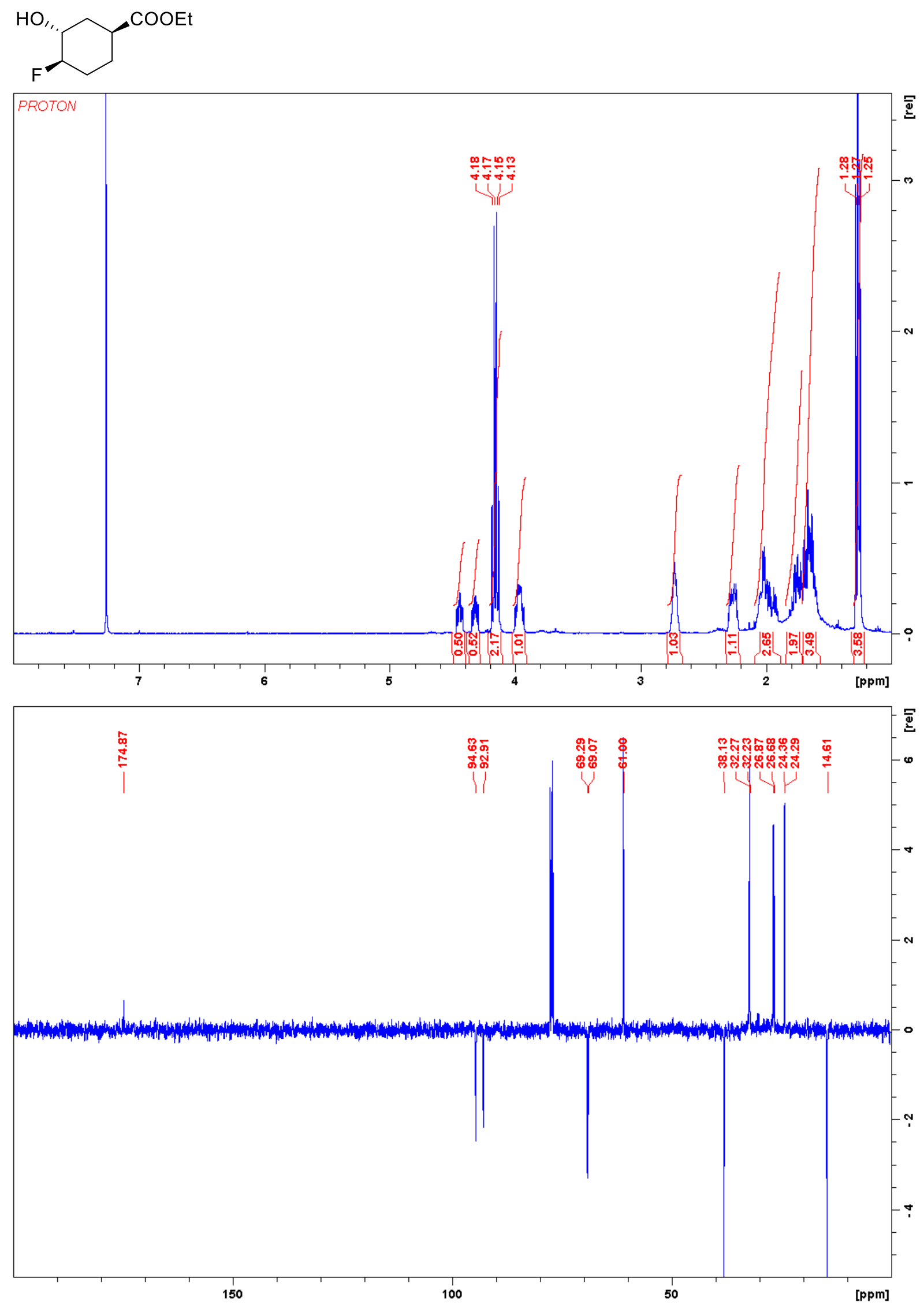
<smiles>CCOC(=O)C1CC[C@@H](O)[C@H](F)C1</smiles>
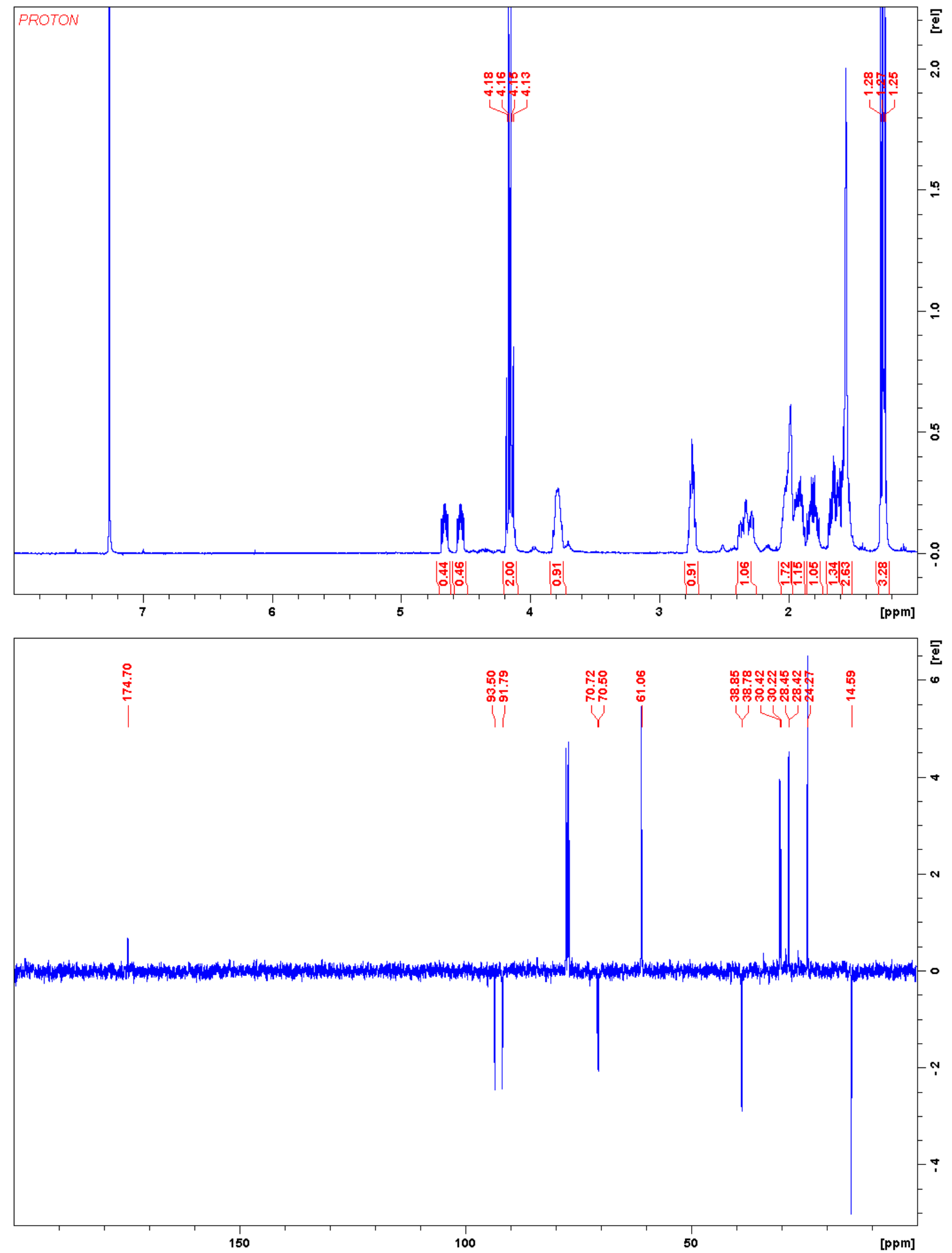
<smiles>CCOC(=O)[C@H]1CC[C@@H](F)[C@H](F)C1</smiles>
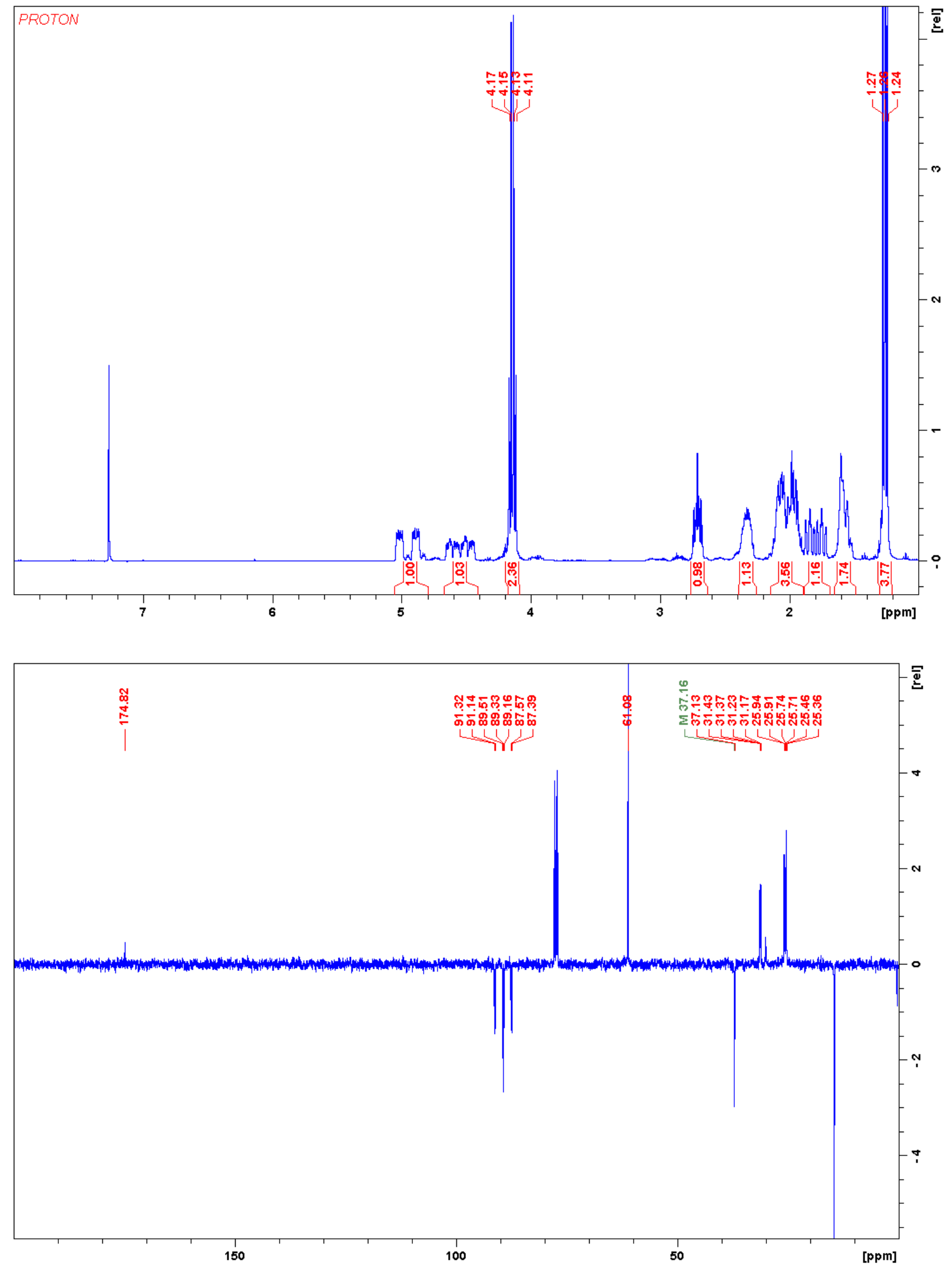
<smiles>O=C(N[C@H]1CC[C@@H](F)[C@H](F)C1)OCc1ccccc1</smiles>
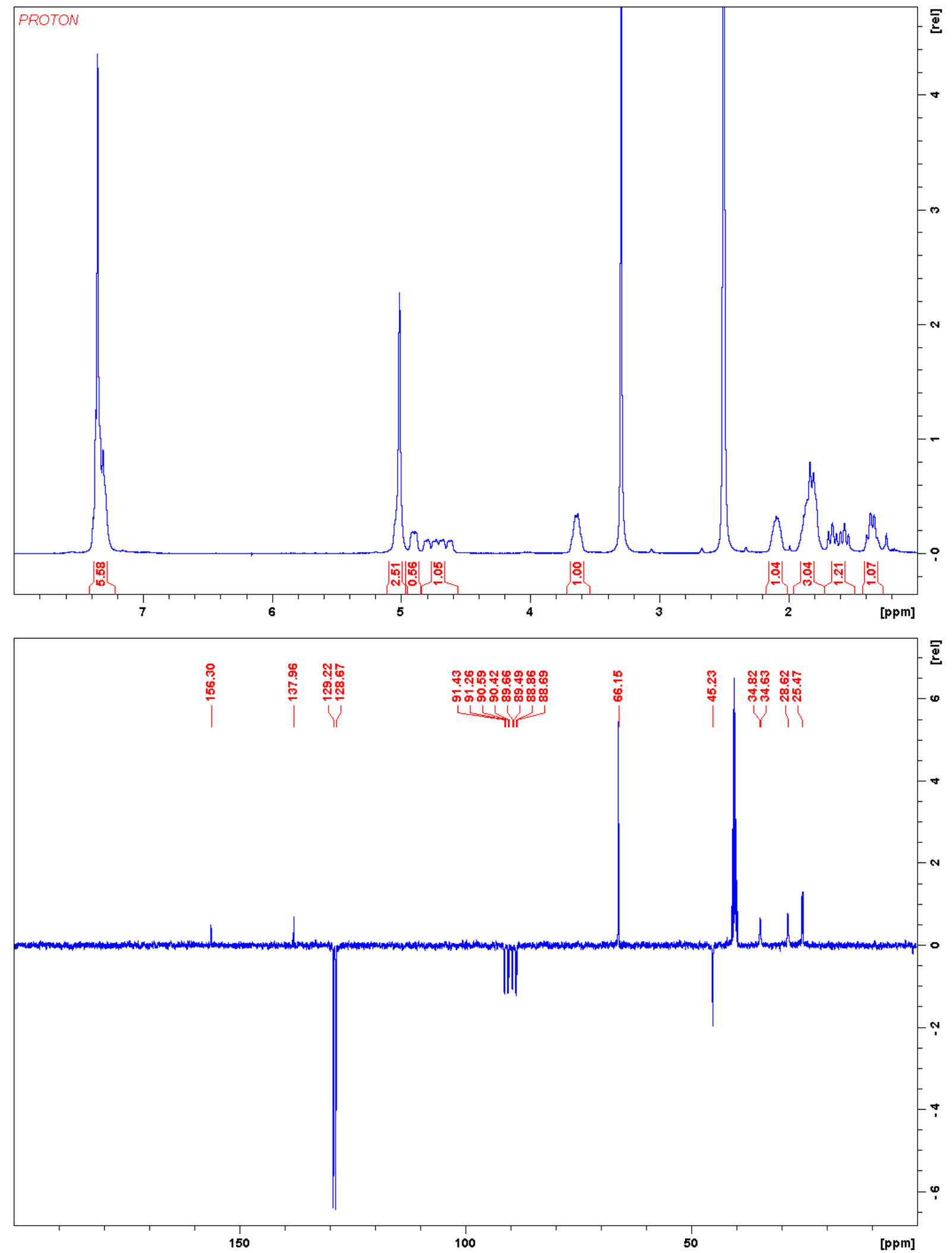